\title{
PENINGKATAN PEMECAHAN MASALAH MATEMATIS MELALUI MODEL MMP BERBANTUAN MODUL ETNOMATEMATIKA PADA SISWA KELAS IV SDN WONOSEKAR
}

\author{
Siti Hannah Nur Fadzillah ${ }^{1}$, Jayanti Putri Purwaningrum², Savitri Wanabuliandari ${ }^{3}$ \\ ${ }^{1}$ PGSD FKIP Universitas Muria Kudus \\ ${ }^{2}$ PMAT FKIP Universitas Muria Kudus \\ ${ }^{3}$ PMAT FKIP Universitas Muria Kudus \\ 1'sitihannahnf@gmail.com , 2jayanti.putri@umk.ac.id , \\ ${ }^{3}$ savitri.wanabuliandari@umk.ac.id
}

\begin{abstract}
This study aims to describe the application of the MMP (Missouri Mathematic Project) model assisted by the ethnomatematics module to improve students' mathematical problem solving abilities and skills in mathematics, as well as how much the teacher's teaching skills can be improved through the MMP (Missouri Mathematic Project) model assisted by the ethnomatematics module. Data collection techniques used in this study consisted of tests and non-tests. The results of the study there are improvements that include the mathematical problem solving ability of students in the first cycle (70\%) increased to (85\%) cycle II, then an increase in the teaching skills of the first cycle teacher (78\%) increased to (91\%) cycle II, and skills students' mathematical problem solving also increased in cycle I (65\%) to (95\%) cycle II. This proves that the application of MMP (Missouri Mathematic Project) learning model assisted by ethnomatematics modules can improve mathematical problem solving abilities and skills as well as teacher teaching skills.
\end{abstract}

Keywords: Problem Solving Skill, MMP, Ethnomatematics Module

\section{ABSTRAK}

Penelitian ini bertujuan mendeskripsikan penerapan model MMP (Missouri Mathematic Project) berbantuan modul etnomatematika dapat meningkatkan kemampuan dan keterampilan pemecahan masalah matematis siswa pada mata pelajaran matematika, serta seberapa besar keterampilan mengajar guru dapat meningkat melalui model MMP (Missouri Mathematic Project) berbantuan modul etnomatematika. Teknik pengumpulam data yang digunakan dalam penelitian ini terdiri dari tes dan non tes. Hasil penelitian terdapat peningkatan yang meliputi kemampuan pemecahan masalah matematis siswa siklus I $(70 \%)$ meningkat menjadi (85\%) siklus II, kemudian terjadi peningkatan pada keterampilan mengajar guru siklus I (78\%) meningkat menjadi (91\%) siklus II, dan keterampilan pemecahan masalah matematis siswa juga terjadi peningkatan pada siklus I (65\%) menjadi (95\%) siklus II. Hal ini membuktikan bahwa penerapan model pembelajaran MMP (Missouri Mathematic Project) berbantuan modul etnomatematika dapat meningkatkan kemampuan dan keterampilan pemecahan masalah matematis serta keterampilan mengajar guru

Kata Kunci: Pemecahan Masalah Matematis, MMP, Modul Etnomatematika. 


\section{A. Pendahuluan}

Undang-Undang

Republik Indonesia Nomor 20 tahun 2003 tentang Sistem Pendidikan Nasional menyatakan bahwa pendidikan adalah usaha sadar dan terencana untuk mewujudkan suasana belajar dan proses pembelajaran agar siswa aktif mengembangkan potensi dirinya untuk memiliki kekuatan spritual, keagamaan, pengendalian diri, kepribadian, kecerdasan, akhlak mulia, serta keterampilan yang diperlukan dirinya, masyarakat, bangsa, dan negara yang berfungsi untuk mengembangkan kemampuan dan serta membentuk karakter peradaban bangsa yang bermartabat dalam rangka mencerdaskan kehidupan bangsa.

Matematika merupakan salah satu pelajaran yang erat kaitannya dengan kehidupan sehari-hari siswa. Semua aktivitas manusia tidak terlepas dari pemanfaatan konsep matematika. Matematika juga merupakan alat berpikir ilmiah, artinya matematika sebagai alat untuk mendapatkan pengetahuan ilmiah dan dapat menghasilkan banyak pernyataan dalam bentuk model matematika (Purwaningrum, 2016).
Dalam hal ini, maka konsep matematika harus ditanamkan pada setiap manusia sejak dini untuk memberi bekal diamasa yang akan datang. Inti pembelajaran matematika yang tertera dalam kurikulum mata pelajaran matematika sekolah di semua jenjang pendidikan, yaitu: mengarah pada kemampuan siswa pada pemecahan masalah yang dihadapi dalam kehidupan sehari-hari, Winarni \& Harmini (2011: 113). Suji (Sapitri, dkk, 2019) mengatakan bahwa pemecahan masalah dalam pembelajaran matematika harus dikembangkan dalam proses pembelajaran dan siswa perlu dibiasakan untuk memecahkan masalah, baik masalah matematis maupun masalah kehidupan sehari-hari. Kemampuan pemecahan masalah merupakan sesuatu yang sangat penting untuk dimiliki siswa dalam pencapaian kurikulum, Husna (Nasution \& Rangkuti, 2019). Hal yang terkait dengan pemecahan masalah tidak akann terlepas dari tokoh utamanya, yaitu George Polya.

Menurut Polya (Roebiyanto \& Harmini, 2017: 38) dalam memecahkan masalah terdapat empat langkah penting yang harus 
dikuasi siswa, yakni memahami masalah, membuat rencana penyelesaian, melaksanakan rencana, dan melihat kembali. Penelitian yang dilakukan oleh JICA Tehnical Cooperation Project for Development of Science and Mathematics Teaching for Primary and Secondary Education in Indonesia (IMSTEP-JICA) (Kania \& Arfin, 2019) pada tahun 1999 menemukan hasil bahwa kemampuan pemecahan masalah matematis merupakan salah satu kegiatan dalam matematika yang dipandang sulit oleh siswa dalam belajar dan guru dalam mengajar.

Hasil observasi dan wawancara dengan guru kelas IV SDN Wonosekar, menunjukan bahwa kemampuan dan keterampilan pemecahan masalah matematis siswa masih rendah. Hal tersebut dikarenakan pelajaran matematika kurang diminati oleh siswa. Mereka beranggapan bahwa matematika merupakan pelajaran yang sulit dikarenakan banyaknya rumus yang harus dihafalkan. Selain itu guru masih menggunakan model pembelajaran konvensional seperti, ceramah dan pemberian tugas mengakibatkan siswa cenderung pasif dalam pembelajaran sehingga membuat turunnya antusias dan motivasi siswa, yang mengakibatkan kurangnya ketertarikan siswa dalam pembelajaran matematika.

Dalam penggunaan bahan ajar guru lebih sering menggunakan bahan ajar cetak atau paket yang telah disediakan oleh pemerintah. Bahan ajar yang tersedia belum memuat soal-soal tentang pemecahan masalah. Sering kali ditemukan bahan ajar yang digunakan masih terfokus pada materi yang terdapat pada kurikulum sehingga siswa cenderung hanya menghafal tanpa memahami konsep dan maknanya.

Selain buku paket, bahan ajar lain yang digunakan adalah LKS dari penerbit yang berisi soal-soal pelajaran. Banyaknya soal-soal yang tergolong bukan pemecahan masalah pada bahan ajar cetak mengakibatkan, Akan kesulitanya siswa dalam menyelesaikan masalah yang tidak rutin. Dalam peningkatan kemampuan pemecahan masalah matematis siswa, hendaknya guru merencanakan dan menyusun persiapan yang baik. Salah satu persiapan yang harus di susun adalah bahan ajar pembelajaran. 
Suatu pembelajaran, adanya bahan ajar menjadi suatu tolok ukur keberhasilan, Yaumi (2014: 273). Disisi lain, bahan ajar cetak yang disediakan oleh pemerintah atau LKS dari sebuah penerbit di dalamnya terdapat budaya-budaya lokal yang belum tentu sesuai dengan daerah atau lingkungan belajar siswa. Guru dalam mengelola pembelajaran hanya dikaitkan dengan kehidupan sehari-hari namun belum di kaitkan dengan kebudayaan-kebudayaan daerah.

Padahal kebudayaan dan potensi daerah merupakan asset yang perlu dikembangkan dan dilestarikan, salah satunya digunakan pada bahan ajar pada proses pembelajaran (Oktavianti, dkk, 2017: 37). Pembelajaran dengan memasukkan unsur budaya lokal akann mempermudah siswa dalam memahami konsep matematika karena pembelajaran dialakukan dengan memberikan pengalaman langsung melalui budaya lokal di daerahnya, Ulya \& Rahayu (2017: 21 22). Wanabuliandari dan Purwaningrum, (2018: menambahkan, dalam pembelajaran yang dilaksanakan akann terasa lebih bermakna, jika adanya pemanfaatan kearifan lokal daerah setempat sehingga membuat siswa memahami materi secara konkret. Salah satu bentuk menerapkan pembelajaran berbasis budaya adalah etnomatematika. Pembelajaran etnomatematika selaras dengan hakikat matematika sebagai kegiatan pemecahan masalah dan alat berkomunikasi, Marsigit (Jati, dkk, 2019:2).

Berdasarkan permasalahan di atas, diperlukan sebuah tindakan untuk menyelesaikan masalah pembelajaran matematika yang terdapat di kelas IV SDN Wonosekar. Salah satu solusinya adalah dengan menerapkan model pembelajaran berbantuan modul etnomatematika dalam proses pembelajaran untuk menambah antusias belajar dan pengetahuan. Salah satu model pembelajaran yang dapat meningkatkan kemampuan pemecahan masalah adalah Missouri Mathematic Project.

Missouri Mathematics Project merupakan model yang dirancang untuk meningkatkan kemampuan siswa dalam memahami konsep, menyelesaikan soal-soal, dan memecahkan masalah-masalah Matematika hingga pada akhirnya 
peserta

didik

mampu

mengontruksikan jawaban mereka

sendiri karena banyaknya

pengalaman yang dimiliki dalam menyelesaikan soal-soal latihan,

Febrianti, 2013 (Diantari, dkk 2019).

Model Pembelajaran Missouri

Mathematics Project merupakan

salah satu model dimana model

tersebut dapat memberi peluang

kepada siswa untuk melatih

kepampuan pemecahan masalah dalam pembelajaran matematika (Dwiningrat, dkk, 2014). Dalam pelaksanaannya, model

pembelajaran Missouri Mathematics

Project (MMP) memiliki langkahlangkah yaitu, review, pengembangan, kerja kelompok/kooperatif, seatwork, dan homework.

Berdasarkan penjelasan di atas, tujuan dalam penelitian ini meliputi (1) Untuk mengetahui peningkatan kemampuan pemecahan masalah matematika melalui model Missouri Mathematics Project (MMP) berbantuan modul etnomatematika pada siswa kelas IV SDN Wonosekar, (2) Untuk mengetahui peningkatan keterampilan guru dalam mengelola pembelajaran matematika melalui model Missouri Mathematics
Project (MMP) berbantuan modul Etnomatematika pada siswa kelas IV SDN Wonosekar,

(3) Untuk mengetahui

peningkatan keterampilan proses pemecahan masalah matematis siswa pada materi bangun datar melalui model Missouri Mathematics Project (MMP) berbantuan Modul Etnmatematika pada siswa kelas IV SDN Wonosekar.

\section{B. Metode Penelitian}

Jenis penelitian yang dilakukan dalam penelitian ini adalah penelitian tindakan kelas yang dilaksanakan pada siswa kelas IV SDN Wonosekar semsester 2 tahun ajar 2019/2020. Penelitian ini dilaksanakan dari observasi pra siklus hingga dilaksanakan tindakan. Subjek dalam penelitian ini yaitu guru dan siswa kelas IV SDN Wonosekar. Subjek kelas IV berjumlah 20 siswa, terdiri dari 6 siswa laki-laki dan 14 siswa perempuan.

Peneliti melakukan penelitian di kelas IV SDN Wonosekar dikarenakan terdapat permasalahan di sekolah tersebut yang perlu ditindak lanjuti. Permasalahan yang terjadi di SDN Wonosekar berdasarkan hasil Pra Siklus yang 
telah dilaksanakkan sebelumnya adalah rendahnya kemampuan peemcahan masalah matematis dan keterampilan proses pemecahan masalah matematis yang dimiliki oleh siswa. Penelitian tindakan kelas dilaksanakan dalam 2 siklus menggunakan model yang dikemukakan oleh Kemmis \& Mc Taggart.

Teknik pengumpulan data yang digunakan dalam penelitian ini terdiri dari tes dan non tes. Instrumen tes digunakan untuk mengukur kemampuan pemecahan masalah matematis. Adapun teknik non tes yang digunakan adalah wawancara, observasi dan dokumentasi. Teknik analisis data yang digunakan dalam penelitian ini adalah analisis data kualitatif dan kuantitatif. Data kualitatif dianalisis menggunakan teknik analisis deskriptif sedangkan data kuantitatif disajikan dalam bentuk persentase dan angka.

\section{C.Hasil Penelitian dan}

\section{Pembahasan}

Penelitian tindakan kelas ini dilaksanakan sebanyak dua siklus untuk mengetahui peningkatan kemampuan dan keterampilan pemecahan masalah matematis siswa dalam pembelajaran siklus I dan siklus II. Sebelum melaksanakan siklus I, peneliti melaksanakan penelitian pra-siklus terlebih dahulu dengan tujuan untuk memperoleh data kondisi awal peserta didik dan guru sebelum adanya tindakan. Prasiklus digunakan peneliti mencari solusi serta tindakan terhadap masalah yang ditemui.

Hasil wawancara dan observasi yang dilakukan oleh peneliti menunjukkan bahwa terdapat masalah dalam pembelajaran yaitu kemampuan dan keterampilan pemecahan masalah matematis siswa siswa masih rendah dan keterampilan mengajar guru dalam pembelajaran masih pada kriteria cukup. Hasil kemampuan pemecahan masalah matematis siswa pada pra siklus menmperoleh rata-rata sebesar 48 dengan ketuntasan klasikal sebesar 15\%. Sedangkan hasil observasi keterampilan pemecahan masalah matematis siswa memperoleh rata-rata sebesar 43.

Tabel 1 Nilai Kemampuan Pemecahan Masalah Matematis Prasiklus

\begin{tabular}{|c|c|}
\hline Jumlah Nilai & 966 \\
\hline $\begin{array}{c}\text { Nilai } \\
\text { Tertinggi }\end{array}$ & 74 \\
\hline $\begin{array}{c}\text { Nilai } \\
\text { Terendah }\end{array}$ & 20 \\
\hline KKM & 70 \\
\hline $\begin{array}{c}\text { Nilai Rata- } \\
\text { Rata } \\
\end{array}$ & $\begin{array}{c}\text { Perlu } \\
\text { Bimbingan }\end{array}$ \\
\hline
\end{tabular}


Tabel 2 Hasil Observasi Keterampilan Pemecahan Masalah Matematis Prasiklus

\begin{tabular}{cc}
\hline Jumlah Skor & 147 \\
\hline Jumlah Nilai & 922 \\
\hline Nilai Rata-Rata & 43 \\
\hline Tingkat & $\begin{array}{c}\text { Perlu } \\
\text { Keberhasilan }\end{array}$ \\
\hline
\end{tabular}

Dari kedua tabel di atas

menunjukan bahwa, nilai rata-rata yang diperoleh berada di bawah nilai KKM yang telah ditentukan dan menempati tingkat keberhasilan perlu adanya bimbingan. Hasil kemampuan pemecahan masalah matematis siswa pada siklus I diperoleh rata-rata sebesar 70 dengan persentase ketuntasan klasikal sebesar 70\%. Sedangkan pada siklus II diperoleh rata-rata sebesar 82 dengan persentase ketuntasan klasikal sebesar 85\%.

Tabel 3 Perbandingan Ketuntasan Belajar Klasikal Siklus I \& II

\begin{tabular}{|c|c|c|c|c|}
\hline \multirow[b]{2}{*}{$\begin{array}{c}\text { Ketuntasan } \\
\text { Belajar }\end{array}$} & \multicolumn{2}{|c|}{ Siklus I } & \multicolumn{2}{|c|}{ Siklus II } \\
\hline & $\begin{array}{c}\Sigma \\
\text { Siswa }\end{array}$ & $\%$ & $\begin{array}{c}\Sigma \\
\text { Siswa }\end{array}$ & $\%$ \\
\hline Tuntas & 14 & $70 \%$ & 17 & $85 \%$ \\
\hline $\begin{array}{c}\text { Tidak } \\
\text { Tuntas }\end{array}$ & 6 & $30 \%$ & 3 & $15 \%$ \\
\hline Jumlah & 20 & $100 \%$ & 20 & $100 \%$ \\
\hline
\end{tabular}

menunjukan bahwa terjadi peningkatan hasil ketuntasan klasikal pada mata pelajaran matematika kelas IV SDN Wonosekar dari siklus I dan siklus II. Dapat disimpulkan bahwa persentase ketuntasan klasikal siswa kelas IV SDN Wonosekar sudah mencapai indikator yang ditetapkan yaitu $\geq 75 \%$. Wilianto (2018: 54) menjelaskan bahwa suatu pembelajaran dikatakan efektif jika memenuhi syarat klasikal sekurangkurangnya $75 \%$ dari jumlah siswa.

Berdasarkan pemaparan di atas, dapat disimpulkan bahwa hasil evaluasi meningkat setiap siklusnya. Hal tersebut sesuai dengan penelitian yang dilakukan oleh Fatmahanik (2016) bahwa hasil tes pada siklus I yaitu 78\% meningkat pada siklus II yaitu $90 \%$. Pada siklus II hasil belajar siswa yang tuntas mencapai $85 \%$ secara klasikal. Hasil yang didapat pada siklus II ini menjadi acuan untuk tidak melakukan pembelajaran di siklus berikutnya sehingga penelitian diberhentikan di siklus II.

Pada Hasil observasi keterampilan pemecahan masalah matematis siswa pada siklus I memperoleh skor sebanyak 1471 dengan rata-rata nilai 74 dan berada pada kualifikasi cukup. Sedangkan pada siklus II diperoleh skor sebanyak 1663 dengan rata-rata nilai 83 dan berada pada kualifikasi baik. e

Dari hasil observasi tersebut, dapat dikatakan bahwa keterampilan pemechaan masalah matematis siklus I dan siklus II mengalami peningkatan. Sejalan dengan Giarti 
Tabel 4 Perbandingan Keterampilan Pemecahan Masalah matematis Siklus I dan Siklus II

\begin{tabular}{ccc}
\hline & Siklus I & Siklus II \\
\hline Jumlah Nilai & 1471 & 1663 \\
\hline $\begin{array}{c}\text { Rata-Rata } \\
\text { Nilai }\end{array}$ & 74 & 83 \\
\hline Kriteria & Cukup & Baik \\
\hline$(2014) \quad$ menyatakan & keterampilan
\end{tabular}

proses pemecahan masalah matematika siswa kelas VI mengalami peningkatan sebesar 28 , 54\% untuk siklus 1 dan 35, $46 \%$ untuk siklus 2. Dengan hal ini, dapat ditarik kesimpulan bahwa keterampilan pemecahan masalah matematis siswa telah memenuhi indikator keberhasilan yaitu siswa memperoleh nilai rata-rata $\geq 70$ dengan tingkat keberhasilan cukup.

Hasil observasi keterampilan mengajar guru menggunakan model MMP berbantuan modul etnomatematika pada pertemuan pertama memperoleh skor sebanyak 75 dengan persentase $75 \%$ atau kualifikasi cukup. Sedangkan pada pertemuan kedua memperoleh skor sebanyak 80 dengan persentase $80 \%$ atau kualifikasi baik. Kesimpulan yang dapat diambil berdasarkan data di atas adalah terjadi peningkatan pada setiap pertemuan di siklus I. Sehingga memperoleh rata-rata keseluruhan pada siklus I memperoleh skor 78 dengan persentase rata-rata sebesar $78 \%$ atau kualifikasi baik.

Pada siklus II, observasi mengajar guru hanya dilakukan satu kali pertemuan dengan hasil skor yan dperoleh sebesar 91 dengan persentase rata-rata sebesar 91\% atau kualifikasi sangat baik. Dari hasil observasi tersebut, dapat disimpulkan bahwa terjadi peningkatan observasi keterampilan mengajar guru pada siklus I ke siklus II.

Tabel 5 Perbandingan Keterampilan

Mengajar Guru Pada Siklus I \& II

\begin{tabular}{ccc}
\hline & Siklus I & Siklus II \\
\hline Jumlah Skor & 78 & 91 \\
\hline Persentase & $78 \%$ & $91 \%$ \\
\hline Kualifikasi & Baik & $\begin{array}{c}\text { Sangat } \\
\text { Baik }\end{array}$ \\
\hline $\begin{array}{c}\text { Tingkat } \\
\text { Keberhasilan } \\
\text { Rata-Rata } \\
\begin{array}{c}\text { Persentase Slklus } \\
\text { I dan II }\end{array}\end{array}$ & Berhasil & Berhasil \\
\hline Berdasarkan & tabel & di atas \\
dapat disimpulkan & bahwa
\end{tabular}

keterampilan mengajar guru sudah mencapai indikator tingkat keberhasilan yang sudah ditetapkan yaitu mencapai kriteria baik.

Secara singkat dan jelas uraikan hasil yang diperoleh dan dilengkapi dengan pembahasan yang mengupas tentang hasil yang telah didapatkan dengan teori pendukung yang digunakan hasil dari pembahsan sebelumnya. 


\section{E. Kesimpulan}

Berdasarkan hasil penelitian tindakan kelas yang sudah dilaksanakan di dapat disimpulkan bahwa (1) Penerapan model Missouri Mathematics Project berbantuan modul etnomatematika dapat meningkatkan keterampilan mengajar guru dalam mengelola pembelajaran. Terlihat pada persentase klasikal siklus I sebesar $78 \%$ dengan tingkat keberhasilan baik, dan siklus II meningkat menjadi $91 \%$ dengan tingkat keberhasilan sangat baik, (2) Penerapan model Missouri Mathematics Project berbantuan modul etnomatematika dapat meningkatkan kemampuan pemecahan amsalah matematis siswa. Terlihat pada hasil prasiklus yang memperoleh niali rata-rata sebesra 48 dengan persentase ketuntasan klasikal sebesar 15\% dengan kriteria perlu bimbingan, meningkat menjadi 70 dengan persentase ketuntasan klasikal sebesar $70 \%$ dengan kriterian cukup pada siklus I, dan meningkat lagi pada siklus II menjadi 82 dengan persentase ketuntasan klasikal sebesar 85\% dengan kriteria baik, (3) Penerapan model Missouri Mathematics Project berbantuan modul etnomatematika dapat meningkatkan keterampilan pemecahan masalah matematis siswa. Terlihat pada hasil prasiklus yang memperoleh nilai rata-rata 46 dengan kriteria perlu bimbingan, meningkat menjadi 74 dengan kriterian cukup pada siklus I, dan meningkat lagi pada siklus II menjadi 84 dengan kriteria baik.

\section{DAFTAR PUSTAKA}

Diantari, A, Gading, K, dan Japa, N. (2019). Pengaruh Model Pembelajaran Missouri Mathematics Project Realistik Berbantuan Lks Terhadap Hasil Belajar Matematika. JIPP: Jurnal IImiah Pendidikan dan Pembelajaran, 3 (2).

Dwiningrat, A.A, Suniasih, dan Manuba, Surya. (2014). Pengaruh Model Pembelajaran Missouri Mathematics Project Terhadap Kemampuan Pemecahan Masalah Matematika Siswa. E-journal MIMBAR PGSD Universitas Pendidikan Ganesha, 2 (1).

Fatmahanik, Ulum. (2016). Realistic Mathematic Education (RME) Dalam Meningkatkan Hasil Belajar Matematika. IBRIES: Jurnal Kependidikan Dasar Islam Berbasis Sains. Vol. 1 (1).

Giarti, Sri. (2014). Peningkatan Keterampilan Proses Pemecahan Masalah Dan Hasil Belajar 
Matematika Menggunakan Model $\mathrm{Pbl}$ Terintegrasi Penilaian Autentik Pada Siswa Kelas VI SDN 2 Bengle, Wonosegoro. Scholaria, Vol.4 (3).

Jati, Suryandaru Prasetyo, Mastur, Z, dan Asikin, M. (2019). Potensi Etnomatematika untuk Mengembangkan Kemampuan Komunikasi Matematis. PRISMA, Prosiding Seminar Nasional Matematika, 2, 277-286. Universitas Negeri Semarang,

Kania, Nia dan Arifin Zaenal. (2019). Analisis Kesulitan Calon Guru Sekolah Dasar Dalam Menyelesaikan Soal Pemecahan Masalah Matematis Berdasarkan Prosedur Newman. SJME: Supremum Journal of Mathematics Education. 3 (1), 5766.

Nasution, Ahmad Sukri dan Rangkuti. Darmina. E.S. (2019). Pengembangan Bahan Ajar Matematika Berbasis Masalah Untuk Meningkatkan Kemampuan Pemecahan Masalah Siswa. Prosiding Seminar Nasional \& Exspo Hasil Penelitian dan Pengabdian Masyarakat. Universitas Muslim Nusantara Al-Washliyah, 2019.

Oktavianti, Ika, dkk. (2017). Menggagas Kajian Kearifan Budaya Lokal di Sekolah Dasar Melalui Gerakan Literasi Sekolah. Prosiding Seminar Nasioanl Aktualisasi Kurikulum 2013 di Sekolah Dasar Melalui Gerakan Literasi Sekolah Untuk Menyiapkan Generasi Unggul dan berbudi Pekerti. Fakultas
Keguruan dan Ilmu Pendidikan Universitas Muria Kudus, Kudus 15 Maret 2017.

Purwaningrum, J. P. (2016). Mengembangkan Kemampuan Berpikir Kreatif Matematis melalui Discovery Learning Berbasis Scientific Approach. Refleksi Edukatika, 6 (2): 145-157

Roebyanto, Goenawan dan Harmini, Sri. (2017). Pemecahan Masalah Matematika. Bandung: PT Remaja Rosdakarya Offset.

Sapitri, Yesi, Utami, Citra dan Mariyam. (2019). Analisis Kemampuan Pemecahan Masalah Matematis Siswa dalam Menyelesaikan Soal Open-Ended pada Materi Lingkaran Ditinjau dari Minat Belajar. Variabel, 2 (1), 16-23.

Ulya, H dan Rahayu, R. (2017). Pembelajaran Etnomatematika Untuk Menurunkan Kecemasan Matematika. Jurnal Mercumatika: Jurnal Penelitian Matematikan dan Pendidikan Matematika, 2 (1), 16-23.

Wanabuliandari, Savitri dan Purwaningrum, Jayanti Putri. (2018). Pembelajaran Matematika Berbasis Kearifan Lokal Gusjigang Kudus Pada Siswa Slow Learner. EduMa, 7 (1), 2086-3918

Wilianto, Irfan, (2018). Efektifitas Penerapan Discovery Learning Berbasis Media Tangram terhadap Pemahaman Konsep Matematis Siswa Kelas IV Sekolah Dasar. Skripsi Tidak diterbitkan. Kudus: Program Studi 
Pendidikan Guru Sekolah Dasar UMK Kudus.

Winarni, Endang Setyo dan Harmini,

Sri. (2011). Matematika Untuk

PGSD. Bandung: PT Remaja

Rosdakarya Offset. 